\title{
DEVELOMPENT OF A VEHICLE SECURITY SYSTEM WITH LOCAL AND REMOTE CONTROL AND EVENT NOTIFICATIONS
}

\section{DESARROLLO DE UN SISTEMA DE SEGURIDAD PARA VEHICULOS CON NOTIFICICACIÓN DE EVENTOS Y FUNCIONES DE CONTROL REMOTO Y LOCAL}

\begin{abstract}
This article describes the development of a security monitoring device for vehicles which gives instant reports to the user about any anomaly that occurs in his absence. This device also allows remote and local control actions, using GSM technology and Bluetooth, giving more functionality than common vehicle security systems. In this paper the different development stages are presented, starting with a short review about existing relevant devices in order to identify the necessary functional requirements and innovation opportunities. Later, a block diagram of the device is presented and the specific design parameter are detailed. The final experimentation showed that the developed equipment has a greater functionality than existing devices and lower production cost.
\end{abstract}

Key words: alarm systems, automotive engineering, bluetooth, GSM.

\section{RESUMEN}

Este artículo describe el desarrollo de un Sistema de seguridad y monitoreo para vehículos capaz de generar reportes al usuario acerca de los eventos que ocurren en su ausencia. El dispositivo permite además realizar acciones de control remoto y local mediante tecnología GSM y Bluetooth, dando una mayor funcionalidad que los dispositivos de seguridad para vehículos comunes. En este trabajo se presentan las distintas etapas del desarrollo, comenzando con una breve reseña de los dispositivos existentes con el fin de identificar los requerimientos funcionales necesarios, junto con oportunidades de innovación. Posteriormente se presenta el diagrama de bloques funcional del dispositivo, detallando los parámetros de diseño utilizados. La experimentación final muestra que el equipo desarrollado posee mayor funcionalidad que los aparatos existentes, con un costo de producción menor.

Palabras clave: bluetooth, GSM, ingeniería automotriz, sistema de alarma.

\section{Juan Manuel Sánchez}

Magister en Administración Docente planta de la Universidad Distrital Francisco José de Caldas jmsanchezc@udistrital.edu.co Bogotá, Colombia

\section{Omar Sogamoso Heredia}

Estudiante de Ingeniería Electrónica Universidad Manuela Beltrán omsogamoso@umb.edu.co Bogotá, Colombia

\section{Edwin Villarreal López}

Magíster en Automatización Industrial Docente Investigador Universidad Manuela Beltrán edwin.villarreal@umb.edu.co Bogotá, Colombia

Tipo: Artículo reporte de caso

Fecha de Recepción: Octubre 19 de 2013 Fecha de Aceptación: Diciembre 22 de 2013 


\section{INTRODUCTION}

Car robbery is one of the most frequent crimes in big cities of countries which are in development process. In Colombia, according to [1] in the year 2010, about 7.094 cars were stolen and only 3.288 of these had insurance policies, causing large losses and raising insurance costs. Additionally, most of partial robbery events are not even reported because of the high cost of insurance reclamation.

Despite of that, most of the extended vehicle security systems consist of an audible alarm, together with a blinking of the main lights. This system is usually factory equipped in many similar cars allowing to be easily disarmed, because of the great amount of public information about its operation [2].

Some others more advanced vehicle security systems are available in the market usually at high cost. For example systems like [3] [4] allow the user to locate the vehicle and perform some other actions like open doors without keys or start the engine remotely. These devices usually require connection with a central station besides monthly payment, which limits its application in a very small market (About 51.000 users [1]).

There are some other alarms with remote report functionality using GSM networks [5] [6]. Unfortunately many of these devices are not available in Colombia. These devices have not been widely used because of its exclusive dependence of the Cellular network availability. On the other hand, there have been some other developments focused on near wireless communications in order to perform local control actions [7] [8]. However, these devices usually lack of remote report notification.

In [9]-[12], devices for vehicle security systems are developed including wireless control and remote anomaly notification. However, these designs are still conceptual and are not present in local market. This influences the final consumer cost making them not accessible.

According to this, there is an innovation oppor- tunity in the development of a low cost device that combines the remote notification and control with local wireless capabilities.

This article is structured as follows: Initially, the general block structure of the proposed device is presented and the detailed design of each component is exposed. Later, some functional tests are performed in order to verify the achievement of functional requirements. Finally a comparative analysis between the designed device and existing products is done in order to draw some conclusions and identify future research opportunities.

\section{METHODOLOGY}

The figure 1 shows the main functional blocks that compose the proposed device, starting with the control module which interacts with the communication hardware. The working parameters are adjusted using a mobile application based interface. There is also a sensor module that detects any anomaly around the vehicle.

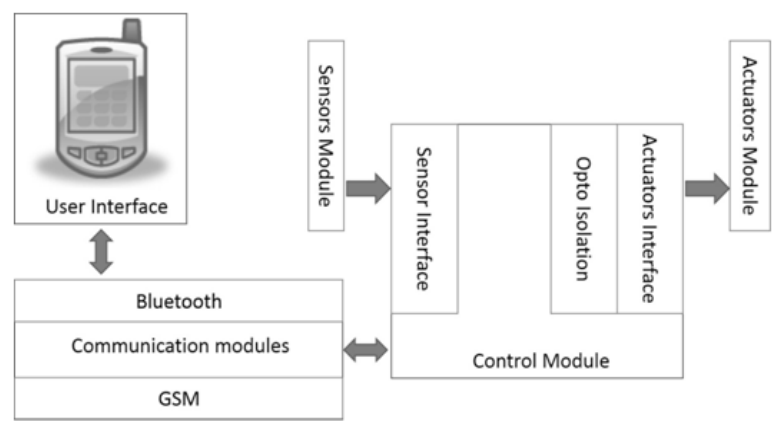

Figure 1. System architecture

\subsection{User interface}

In order to operate the different capabilities included in the prototype, an application for mobile devices has been made. Java and specifically JME [13] was used as the development environment since it allows compatibility with most of the mobile hardware platforms existing today, because of its virtual machine oriented approach that ensures the operation in multiple operative systems. The functional requirements for this software are listed below. 
For user handling

- Creating the users profile and their privileges

- Defining passwords and phone numbers for notification

For local access

- Configuring the connection with Bluetooth devices through a secure password

- Handling local commands like open doors, engine starting and doors lock.

- Blocking the vehicle

- Activating or deactivate the system

For remote access

- Getting anomaly notifications through SMS service
- Handling remote control actions like turn off the engine and door unlocking.

- Blocking the vehicle.

Figure 2 left shows the flow diagram of the authentication process. Initially, when the mobile device requests for connection, the system checks the device id and password, allowing or declining the connection. If the connection is successful, a menu is displayed where the user selects between control and configuration tasks. The control flow diagram (figure 2 right) allows the user to choose the desired control action among engine activation, door locking or car blocking. On the other hand, the configuration process gives access to the user database that includes Bluetooth id, device name and password configuration, phone number for SMS reports and message configuration.

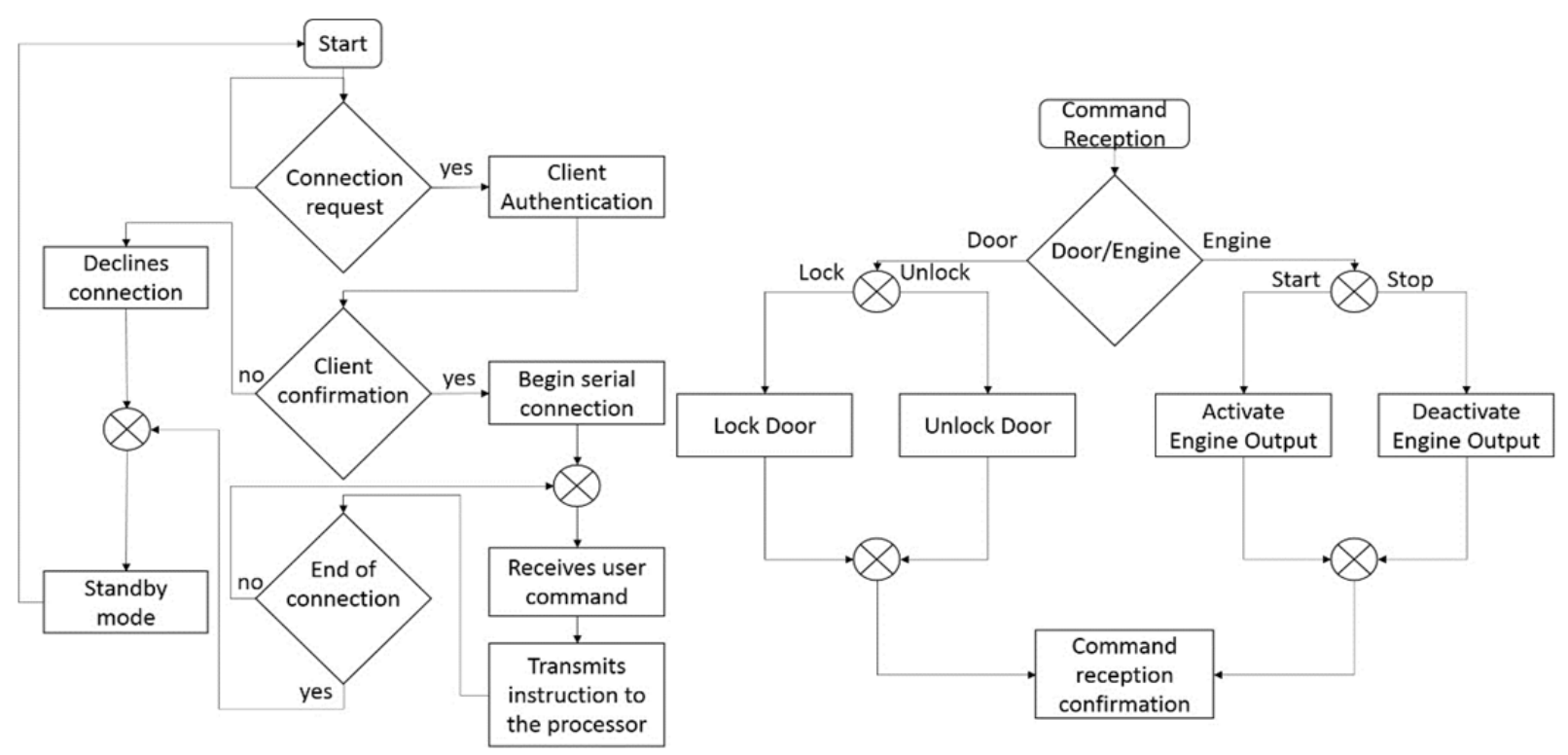

Figure 2. Flow diagrams. Authentication process (left), command actions (right)

\subsection{Sensors module}

This module is composed for different kind of sensors that are usually installed in car security systems such as impact detectors, touch sensors, movement and starting indicators and door opening. As report messages are configurable, it is possible to include some other kind of sensor if they have a binary digital output. Figure 3 presents different sensor configurations that can be used. 


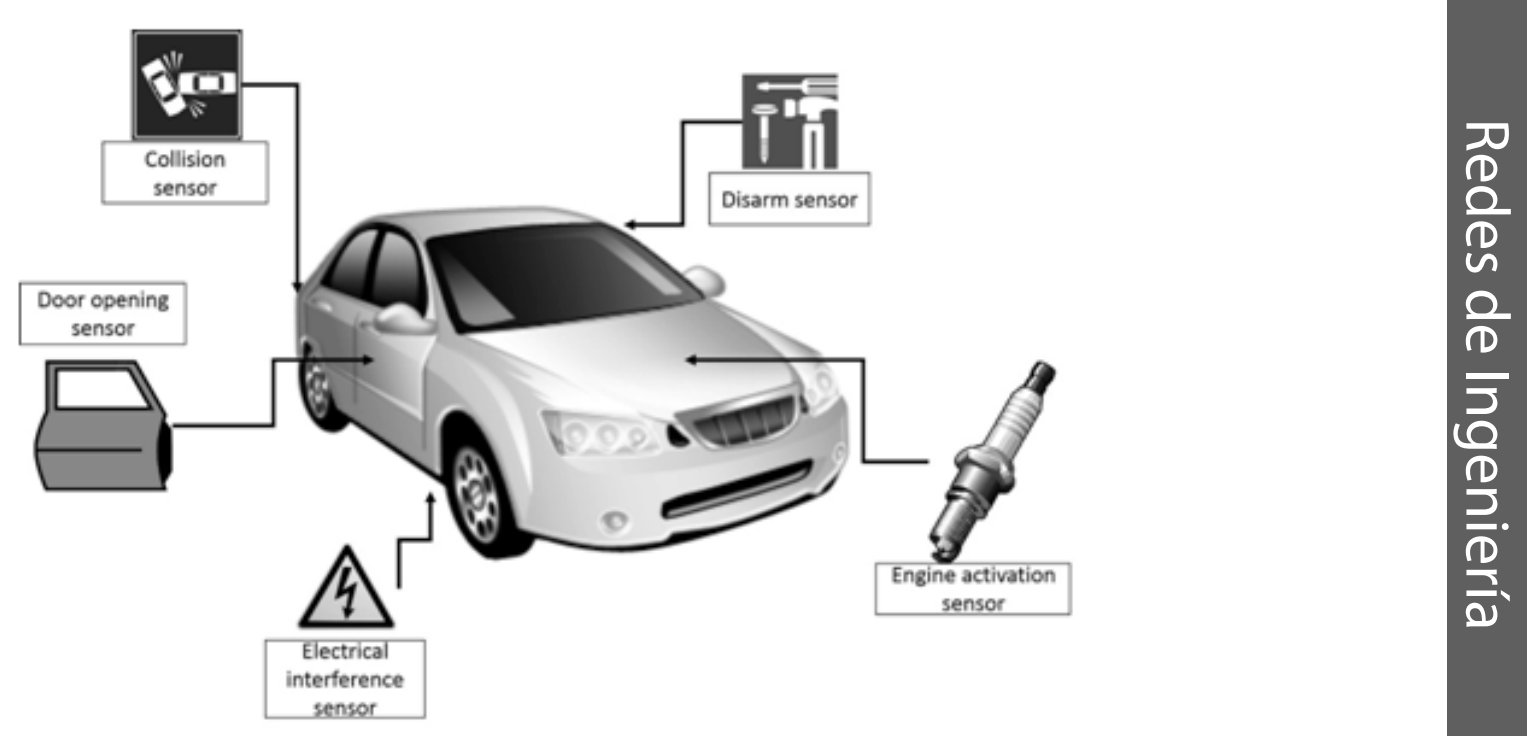

Figure 3. Regular sensor configuration options

\subsection{Actuator module}

It comprises 5 digital isolated outputs that can handle different kind of loads as electronic sirens and lights. Outputs can also be used to disable the vehicle and to lock and unlock the doors. Other control actions that can be configured are the window opening and engine starting. System functionality depends on the installation configuration and vehicle compatibility, as some of them have closed electronic systems which makes difficult the integration with external hardware.

\subsection{Communication module}

This module comprises close wireless communication through a Bluetooth connection adapter. The selected device was the KC-21 from KCWirefree [14]. Its main features are the multiple working configurations which allows easy UART connection and AT commands compatibility [15].

On the other hand, the long range communications can be performed using a cell phone or any other GSM device compatible with serial AT commands. The recommended device is the Quectel M80 adapter [16], because of its low power consumption, small package and low price.

\subsection{Main control unit}

It is primarily composed by a microcontroller of the Microchip family and interface components that allow the interface with communication modules, input sensors and output actuators. The functions of the Main Control Unit can be divided in two groups; when an anomaly has been detected or when the user wants to control the system on Bluetooth control mode. The detailed tasks for each case are listed below: Anomaly Detected

- Handling the information that comes from sensors identifying the detected anomaly. When one of the inputs changes its state, an interruption is triggered and the event is identified.

- Taking automated local actuator actions like activate lights and sound. These actions are preconfigured, but using the mobile control application, they can be changed.

- Automatically locking the vehicle doors and engine starting when an event is detected

- Managing the communication modules in order to send alerts notification to the configured user database. If the user is connected through the Bluetooth adapter, he will receive a direct message, but if the user is out of range, the message will be send using the GSM module 
- Managing control actions sent via SMS messages. The user can block the car remotely for example

\subsection{Bluetooth control mode}

- Configuring the sent alert messages

- Configuring the user database, including privileges and access codes

- Configuring the actuator actions like lights and horn activation and door locking

- Allowing the user control actions including door unlocking, engine activation and window opening.

- Enabling and disable the system

\section{RESULTS}

The final integration of the different modules can be seen in the figure 4 . The printed circuit board developed has the necessary interface components to connect the sensors, actuators and communication modules. The main design parameter for the prototype was to obtain a low production cost using commercial materials. Power components were optically isolated and located avoiding the induction of electronic interferences in the communication and signal processing modules.

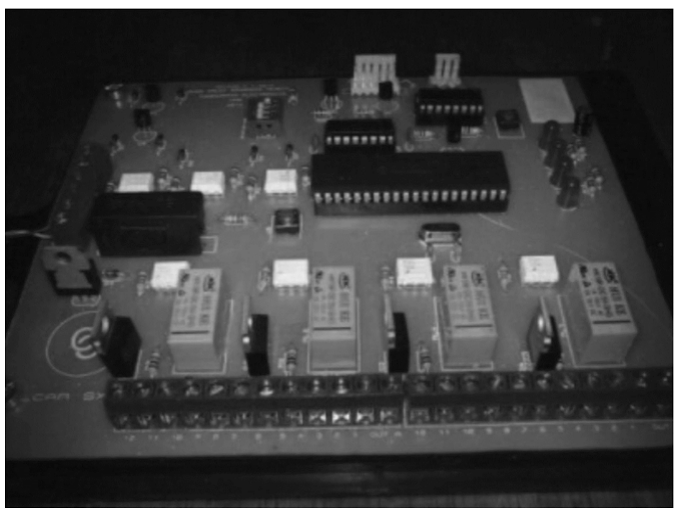

Figure 4. Developed system board3.1.

\subsection{Experimental design}

In order to evaluate the functionality of the prototype, the device was installed into a test environment with the main sensors and actuators available in a car security system. The following tests were conducted in order to provide information about the communication reliability and stability of the system.

Response time vs. communication mode: the table 1 presents the range of 20 tests where the response time of the system was measured. The reaction time when an event has been detected for the sensors was about 0.1 seconds in Bluetooth mode and between 30 and 45 seconds in GSM mode. On the other hand, when the user sends an instruction to the system, the response time was about 0.2 seconds in Bluetooth mode and about 65 and 240 seconds in GSM mode.

Table 1. Response time vs. communication mode

\begin{tabular}{|c|c|c|c|}
\hline Test & Distance & GSM & Bluetooth \\
\hline $\begin{array}{c}\text { Command } \\
\text { from user }\end{array}$ & $10 \mathrm{~m}$ & $30-45$ seconds & 0.2 seconds \\
\cline { 2 - 4 } & $20 \mathrm{~km}$ & $65-240$ seconds & \\
\hline \multirow{2}{*}{$\begin{array}{c}\text { Event } \\
\text { detection }\end{array}$} & $10 \mathrm{~m}$ & $30-45$ seconds & 0,1 seconds \\
\cline { 2 - 4 } & $20 \mathrm{~km}$ & $65-230$ seconds & \\
\hline
\end{tabular}

Bluetooth response vs. distance: the table 2 presents the number of successful received commands for the main control unit when the user varies the distance to the vehicle. It shows that the reliability depends on the distance. Also it is shown that the best performance is accomplished from 1 to 5 meters.

Table 2. Successful bluetooth reception vs. distance

\begin{tabular}{|c|c|c|c|}
\hline Distance & $\begin{array}{c}\text { Number } \\
\text { of send } \\
\text { commands }\end{array}$ & $\begin{array}{c}\text { Number of } \\
\text { received } \\
\text { commands }\end{array}$ & Effectiveness \\
\hline $1-5 \mathrm{~m}$ & 25 & 25 & $100 \%$ \\
\hline $5-7 \mathrm{~m}$ & 25 & 20 & $80 \%$ \\
\hline $7-9 \mathrm{~m}$ & 25 & 7 & $70 \%$ \\
\hline $9-10 \mathrm{~m}$ & 25 & 5 & $50 \%$ \\
\hline$>10 \mathrm{~m}$ & 25 & 0 & $0 \%$ \\
\hline
\end{tabular}

\subsection{Estimated production cost}

The table 3 presents costs of the components involved in the development of the prototype. The estimated components cost is around 200,298 Colombian pesos for prototype and 
142,468 Colombian pesos for low mass production. Combined with a high profit margin (100\%), and $40 \%$ of distribution and installation including taxes, leads to an approximate market price of 398,910 Colombian pesos. This cost is equivalent to the $70 \%$ of regular insurance company reclamation fee, or the $50 \%$ of typical tire replacement cost, which makes the device highly affordable for most of vehicle owners.

Table 3. Estimated production cost

\begin{tabular}{|c|c|c|}
\hline Component & $\begin{array}{c}\text { Prototype cost } \\
\text { (Colombian } \\
\text { pesos) }\end{array}$ & $\begin{array}{c}\text { Massive } \\
\text { production cost } \\
\text { (Colombian } \\
\text { pesos) }\end{array}$ \\
\hline $\begin{array}{c}\text { Kc-21. Bluetooth } \\
\text { module }\end{array}$ & 69,600 & 55,000 \\
\hline $\begin{array}{c}\text { Quectel M80. } \\
\text { GSM module }\end{array}$ & 48,198 & 40,968 \\
\hline Antennas & 35,000 & 27,000 \\
\hline $\begin{array}{c}\text { Integrated } \\
\text { circuits. } \\
\text { (microcontroller } \\
\text { and interface) }\end{array}$ & 15,000 & 10,000 \\
\hline $\begin{array}{c}\text { Isolation } \\
\text { components. } \\
\text { (Relays and } \\
\text { optoisolators) }\end{array}$ & 4,500 & 3,000 \\
\hline $\begin{array}{c}\text { Connectors and } \\
\text { terminals }\end{array}$ & 3,000 & 1,500 \\
\hline $\begin{array}{c}\text { Board } \\
\text { production and } \\
\text { assembly }\end{array}$ & 25,000 & 5,000 \\
\hline
\end{tabular}

\subsection{Market opportunities}

Nowadays, security systems is one of the most common accessories installed in vehicles. According to [17] in the year 2012311,920 new cars and 572,584 motorcycles vehicles were registered in Colombia. Most of them have installed the factory security systems. On the other hand, according to [18], 22,158 vehicles were reported as stolen in the same year, corresponding to the $2,5 \%$ which is a high percentage.

The main governmental strategy against vehicle robbery is the growth of police departments. Despite of this, in the last 6 years the amount of stolen vehicles has shown an uptrend.
This facts exalt the importance of any technological approach that may contribute to solve this problem.

\subsection{Comparative market analysis}

The table 4 presents a comparative analysis between the developed device and the most relevant available products in domestic market where communication compatibility, autonomy and relative cost are taking into account. The conclusion is that the presented design allows higher functionality for a lower cost.

Table 4. Functional comparative analysis

\begin{tabular}{|c|c|c|c|}
\hline Device & $\begin{array}{c}\text { GSM remote } \\
\text { notification }\end{array}$ & Bluetooth & $\begin{array}{c}\text { Requires } \\
\text { regular } \\
\text { payment }\end{array}$ \\
\hline $\begin{array}{c}\text { Described } \\
\text { prototype }\end{array}$ & $\mathrm{X}$ & $\mathrm{X}$ & \\
\hline $\begin{array}{c}\text { Chevistar@ } \\
{[4]}\end{array}$ & $\mathrm{X}$ & $\mathrm{X}$ \\
\hline $\begin{array}{c}\text { Detektor } \\
{[3]}\end{array}$ & $\mathrm{X}$ & $\begin{array}{c}\text { Extra } \\
\text { module }\end{array}$ & Optional \\
\hline
\end{tabular}

\section{CONCLUSIONS}

In this research, the different development stages of a vehicle security system was presented. This system can achieve efficiently event detection and alarm triggering, combined with remote reports to the user through GSM networks, allowing the user be aware of the vehicle state. The systems also provides a multiplatform user interface for mobile devices used for local control and configuration. The functionality analysis establish the efficient event detection and communication abilities of the system where short time response and low range of Bluetooth mode is complemented with remote control capabilities on GSM mode. The identified market opportunities, the production cost estimation and functional comparison with similar devices show a promissory market impact.

\section{FUNDING}

This research was developed as an undergraduate thesis in electronics engineering in the Manuela Beltrán University. 


\section{Referencias Bibliográficas}

[1] . Rodríguez. Comportamiento Histórico de la Industria Aseguradora Colombiana, Fasecolda, Colombia, 2010.

[2] R. Winslow. Enhanced Vehicle Security System, U.S. Patent 20130057396 A1, 2013.

[3] Detektor. Descripción del servicio de seguridad para vehículos, Tracker de Colombia S.A.S [Online]. Available: http://detektor.com.co.

[4] Chevystar. Manual de Usuario Chevystar, Chevrolet de Colombia. [Online]. Available: http://chevrolet.com.co/ chevystar.

[5] Levelna. Car Alarm, GSM, GPRS, GPS, User Guide to Installation and Operation, Level Systems. [Online]. Available: http:// www.levelna.com/positrex

[6] Tracer. Tracer product overview, EWCop. [Online]. Available: http://ewcop.com

[7] I. Choi. System and method for managing vehicle through the wireless communications relay of a vehicle remote controller, U.S. Patent 20120303182, 2010.

[8] S. Zaid, V. Anma \& E. Kroo. Vehicle access control services and platform, U.S. Patent 0110112969, 2011.

[9] Q. Liu, H. Zhang \& B. Zou. Research and design of intelligent vehicle monitoring system based on GPS/GSM, ITS Telecommunications Proceedings, 2006 6th International Conference on. IEEE, 2006.

[10] Q. Y. Niu, W. Y. Zhang M. \& Z. Shang. Authentication Scheme between the Vehicle Alarm with Remote Control and
Mobile Phone. Applied Mechanics and Materials 273 (2013): 551-554.

[11] J.M. Hu, J. Li, \& G. H. Li. Automobile Anti-theft System Based on GSM and GPS Module. Intelligent Networks and Intelligent Systems (ICINIS), 2012 Fifth International Conference on. IEEE, 2012.

[12] H. PENG, \& C.P. LI. Application of Vehicle Anti-theft System Based on RFID and the GSM network. China Integrated Circuit 5 (2012): 022.

[13] F. P. Miller, A. F. Vandome, J. McBrewster. Java Platform, Micro Edition: Java (software Platform), Mobile Device, Embedded System, Mobile Phone, Set-top Box, Sun Microsystems, Java Community Process, Reference Implementation (computing), GNU General Public License, VDM Publishing, 2010.

[14] KCWirefree. KC-21 Class 2 Bluetooth Data Module. [Online]. Available: http:// www.kcwirefree.com

[15] Z. HAN, \& F. LV. Research and Development of Simulation System of AT Commands Based on GSM Network. Modern Electronic Technique 17 (2005).

[16] Quectel. Quectel M80 GSM specifications, Quectel. [Online]. Available: http://www. quectel.com

[17] Andi. Venta de Vehículos año 2012, Colombia, Asociación Nacional de Industriales. [Online]. Available: http:// www.andi.com

[18] L. M. Lozano. Informe Hurto Automotor, Departamento Mercados y Estadísticas, Asopartes, Colombia, 2012. 